\title{
DP -638
}

\section{Copy 41}

Special Distribution

AEC Research and Development Report

NEPTUNIUM BEHAVIOR IN SOLVENT

EXTRACTION OF URANIUM AT

SAVANNAH RIVER PLANT

by

H. E. Henry, D. G. Karraker, and C. S. Schlea

Separations Chemistry Division

September 1961
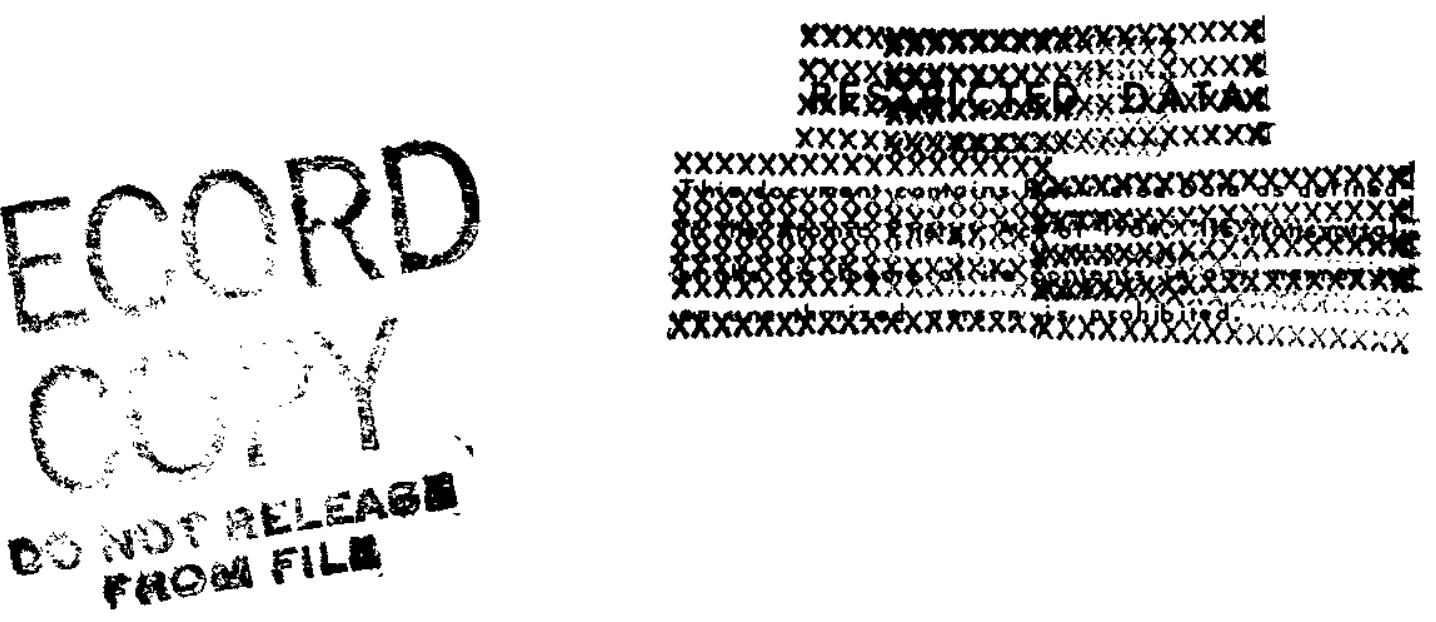

E. I. du Pont de Nemours \& Co.

Savannah River Laboratory

Aiken, South Carolina 
This report was prepared as an account of Government sponsored work. Ne1ther the United States, nor the Commission, nor any person acting on behalf of the Commission:

A. Makes any warranty or representation, expressed or implied, with respect to the accuracy, completeness, on usefulness of the information contained in this report, or that the use of any information, apparatus, method, or process disclosed in this report may not infringe privately owned rights; or

B. Assumes any liabilities with respect to the use of, or for damages resulting from the use of any information, apparatus, method, or process disclosed in this report.

As used in the above, "person acting on behalf of the Commission" includes any employee or contractor of the Commission, or employee of such contractor, to the extent that such employee or contractor of the Commission, or employee of such contractor prepares, disseminates, or provides access to, any information pursuant to his employment or contract with the Commission, or his employment with such contractor. 
UNCLASSIFIE

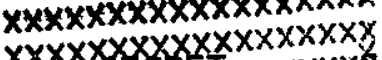
$x \times x \times x \times x \times x \times x \times x \times x$

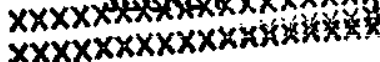

DP -638

SPECIAL DISTRIBUTION

Th1s document cons1sts of

27 Pages, Number 41 of

110 Copies, sectes

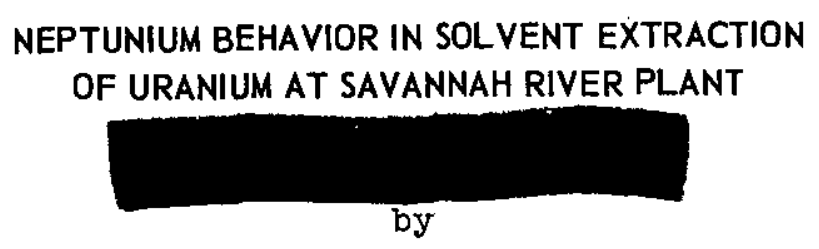

Hugh E. Henry, David G. Karraker, and Carl S. Schlea

September 1961

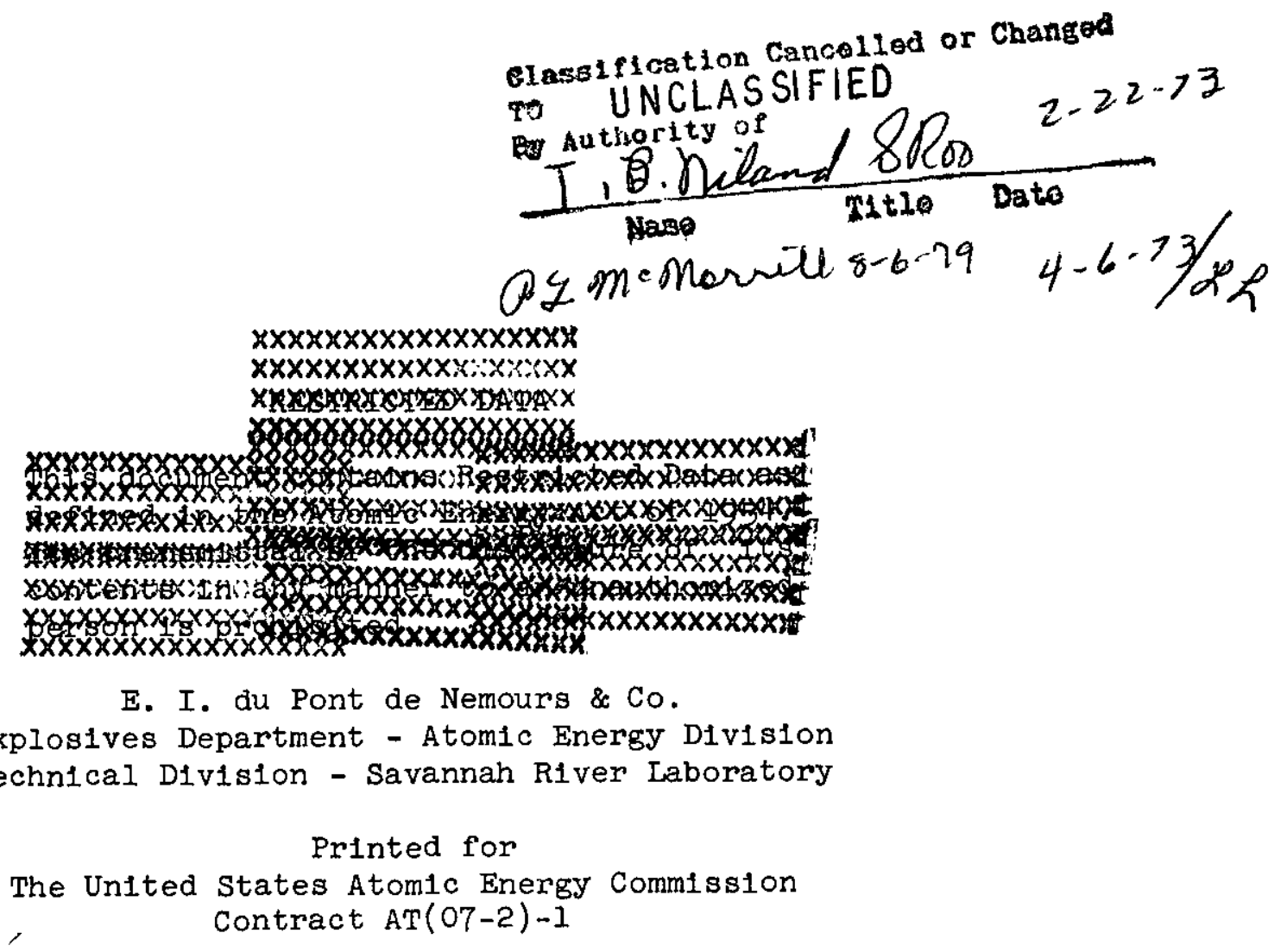

Approved by

C. H. Ice, Research Manager

Separations Chemistry Division 
an.

UNELASSIFIED.

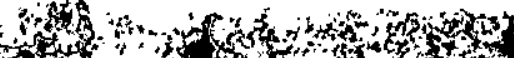

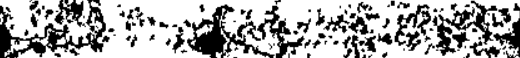

xint?

\section{ABSTRACT}

The solvent extraction behavior of neptunium in the processing of irradiated natural uranium (Purex process) and irradiated enriched uranium (HM process) at Savannah River was studied in the laboratory. Conditions. were demonstrated for extracting neptunium in the first solvent extraction contactor of each process, and two methods were developed for partitioning neptunium from uranium in the HM process.

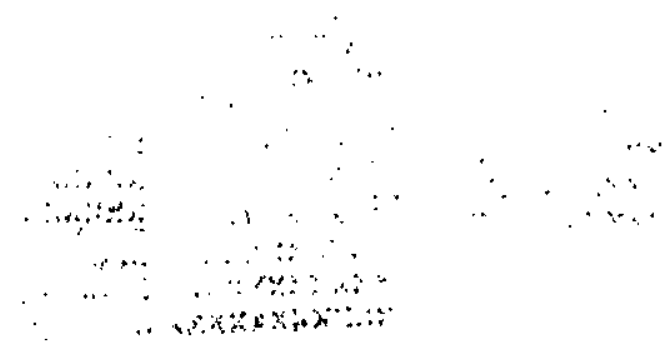




\section{DISTRIBUTION}

Copy No.

1-5. AEC, SROO

6-56. du Pont Company, Atomic Energy D1vision

57. Albuquerque Operations Office

58. Atomic Energy Commission, Washington

59. Ch1cago Patent Group

60. General Electric Company, Richland

61. Hanford Operations office

62. Lawrence Radiation Laboratory (Livermore)

63. Los Alamos Sclentific Laboratory

64. Mound Laboratory

65. Oak Ridge Operations Office

66. Patent Branch, Washington

67. Ph1111ps Petroleum Company (NRTS)

68. San Francisco Operations Office

69. Union Carbide Nuclear Company (ORGDP)

70. Union Carbide Nuclear Company (ORNL)

71-110. Technical Information Service Extension 


\section{CONTENTS}

$\underline{\text { Page }}$

Iist of Tables and Figures

Introduction $\quad 6$

Summary

Discussion 8

Experimental Procedure 8

Purex Process 9

General 9

Extraction of $\mathrm{Np}(\mathrm{VI})$ in the IA Bank 9

Reflux of $\mathrm{Np}$ (IV) in the IA Bank II

HM Process 12

General 12

Extraction of Neptunium in the IA Bank 13

Partition of Neptunium from Uranium in the $1 B$ Bank 14

Extraction of Neptunium in the ID Bank 15

Partition of Neptunium from Uranium in the ID Bank 17

$\begin{array}{ll}\text { B1bllography } & 19\end{array}$ 


\section{LIST OF TABLES AND FIGURES}

$\underline{\text { Page }}$

Table

I Purex Test Flowsheet 10

II Extraction of Neptuntum in Purex Process 10

III HM Flowsheet, IA Bank 13

IV Extraction of Neptunium in 2A Bank in HM Process 13

$V$ Partition of $\mathrm{Np}$ (IV) from Uranium in IB Bank 15

VI Test Flowsheet, ID Bank 16

VII Partition of Np(IV) from Uranium in ID Bank 17

\section{Figure}

1 Outline of SRP Purex Process 20

2 Flow Diagram for Purex Test Flowsheet 21

3 Stage Prof1le of Neptunium in Organic Phase of IA Bank, Purex Process 21

4 Outline of HM Process 22

5 Stage Profile of Np(IV) in Organlc Phase of IA Bank, HM Process

6 Stage Profile of $\mathrm{Np}$ (VI) in Organic Phase of IA Bank, HM Process

7 Effect of Temperature on Distribution of $\mathrm{Np}(\mathrm{IV})$, HM Process

8 Extrapolation of Distribution Data for $\mathrm{Np}$ (IV), HM Process

9 Effect of $\mathrm{pH}$ on Distribution of $\mathrm{Np}$ (IV), HM Process

10 Effect of Aluminum Nitrate on Distribution of $\mathrm{Np}$ (IV), HM Process

11 Effect of N1tric Acid (N1trate) on Distribution of $\mathrm{Np}$ (IV), HM Process

12 Effect of TBP on Distribution of Np(IV), HM Process

13 Effect of Nitric Acid on Distribution of Uranium, HM Process

14 Effect of TBP on Distribution of Uranium, HM Process 
15 Effect of Temperature on Distribution of Uranium, HM Process

16 Distribution of $\mathrm{Np}(\mathrm{VI})$, HM Process 25

17 Stage Profile of Np(VI) in Organic Phase of ID Bank,

18 Stage Profile of $\mathrm{Np}$ in Organic Phase of ID Bank, $0.001 \mathrm{M} \mathrm{HNO}_{2}$ in the Organic Phase, HM Process

19 Stage Profile of Np in Organtc Phase of ID Bank, $0.0005 \mathrm{M} \mathrm{HNO}_{2}$ in the Organic Phase, HM Process

20 Calculated Stage Profile of $\mathrm{Np}$ (IV) in Organic Phase of ID Bank, HM Process 


\section{'UNGLASSIFIED}

\section{NEPTUNIUM BEHAVIOR IN SOLVENT EXTRACTION \\ OF URANIUM AT SAVANNAH RIVER PLANT}

\section{INTRODUCTION}

Several methods were investigated at the Savannah River Laboratory as possibilities for the recovery of neptunium during the processing of irradiated natural uranium (Purex process) or irradiated enriched uranium ( $H M$ process), and the results of these studies are reported here.

In the Savannah River production reactors, $\mathrm{Np}^{237}$ is produced by the following reactions:

$$
\begin{aligned}
& \mathrm{U}^{238} \stackrel{(\mathrm{n}, 2 \mathrm{2n})}{\longrightarrow} \mathrm{U}^{237} \stackrel{\mathrm{B}^{-}}{\longrightarrow} \mathrm{Np} 237 \\
& U^{235}(\mathrm{n}, \gamma)-\bar{U}^{238} \stackrel{-(n, \gamma)}{\longrightarrow} \mathrm{U}^{237} \stackrel{-\beta}{\longrightarrow} \mathrm{N} \overline{\mathrm{p}}^{237}
\end{aligned}
$$

Reaction (1) is the principal source of $\mathrm{Np}^{237}$ from the irradiation of natural uranium; reaction (2) predominates with enriched $U^{235}$ fuel.

In the recovery of neptunium the first step is the isolation of a crude fraction of neptunium at some point in the solvent extraction process. This fraction is then purified in subsequent process steps. The design of the over-all recovery process involves the selection of the method for 1solating neptunium from the solvent extraction process as well as the selection of the method for final purification. The numerous factors that are involved in these selections are not discussed in detall in this report. Rather, emphasis is placed on the solvent extraction behavior of neptunium with the intent of developing information that permits the routing of neptunium to that point in the process that is most advantageous for recovery under any given set of conditions. For example, in some instances it may be desirable to route neptunium directly to the aqueous effluent from the first solvent extraction contactor ( $1 \mathrm{~A}$ bank), and then to recover neptunium from this "waste" after evaporation. Under different circumstances it may be advantageous to extract neptunium in the $1 \mathrm{~A}$ bank and to separate the extracted neptunium from the other actinides at a subsequent stage in the process.

Hanford(1) has reported work on the recovery of neptunium by solvent extraction in the Purex process operated there. Solvent extraction flowsheets were suggested by the Oak Ridge National Laboratory (ORNL) for recovery of neptunium from the Purex process $(2,3,4)$, and several special solvent extraction processes were developed for neptunium purification $(3,4,5)$. The recovery of neptunium from the ORNL process for recovery of irradiated enriched uranium was also reported.

The objective of the work reported here was to develop speclal conditions that would apply to Savannah River processes, equipment, and operating practices. 


\section{SUMMARY}

A study was made of the solvent extraction behavior of neptunium in the Purex process and in the enriched uranium (HM) process at the Savannah River Plant. The objective of this study was to demonstrate conditions in the solvent extraction processes that would permit routing the neptunium to points that would be advantageous for subsequent isolation and purification.

In the Purex process, in which the majority of the neptunium is normally directed to the aqueous waste from the first solvent extraction contactor ( $1 \mathrm{~A}$ bank), conditions were demonstrated for extracting the neptunium with the uranium and plutonium in the $1 \mathrm{~A}$ bank or for refluxing the neptunium in the bank. Neptunium was extracted by adjusting the concentration of nitrous ac1d so that $\mathrm{Np}$ (VI) was present in the bank, and by. adjusting the saturation of the solvent in the scrub section to prevent the reflux of nitrous acid which leads to reduction of $\mathrm{Np}(\mathrm{VI})$ to $\mathrm{Np}(\mathrm{V})$. Neptunlum that was extracted in the $1 \mathrm{~A}$ bank. followed uranium through the first extraction cycle under normal process conditions. Neptunium was refluxed in the IA bank by adding ferrous sulfamate to produce $\mathrm{Np}$ (IV) in the extraction section and by maintaining a nigh saturation in the solvent to prevent the extraction of $\mathrm{Np}$ (IV) in the scrub section.

Neptunium is normally extracted in the $1 \mathrm{~A}$ bank of the HM process. In the second extraction cycle the final distribution of neptunium is about 10-25\% in the aqueous waste from the $1 \mathrm{~A}$ bank, about 50-60\% in the aqueous waste from the ID bank, and about 25-30\% in the final. uranium product. Conditions were demonstrated for increasing the extraction of neptunium as $\mathrm{Np}(I V)$ in the IA bank and for partitioning the extracted neptunium from uranium in the $1 B$ bank. The addition of ferrous sulfamate to the feed improved the extraction of neptunium, and an increase in the solvent flow resulted in a further improvement. In a $1 B$ bank, neptunium was successfully stripped into $4 \mathrm{M}$ nitric acid; less than $2 \%$ of the neptunium remained with the uranium and less than $0.07 \%$ of the total uranium accompanied the neptunium. Conditions were also demonstrated for extracting and partitioning neptunium as $\mathrm{Np}$ (VI); however, this method of operation does not permit the required separation of uranium from plutonium in the first cycle.

If it is not feasible to partition neptunium from uranium in a $1 B$ bank, It is necessary to control the route of neptunium in the second cycle of solvent extraction. Conditions were adjusted in the second cycle so that neptunium was routed to either the final uranium product or the aqueous waste from the first contactor (ID bank). Neptunium was routed to the aqueous waste by reducing the normal acidity of the scrub solution, and was routed to the uranium product by adding $\mathrm{Ce}$ (IV) to produce $\mathrm{Np}(\mathrm{VI})$ in the bank. 
As in the Purex process, the selection of a method for the recovery of neptunium from the HM process depends on a number of factors, including constraints placed upon the process by other requirements and upon the avaliability of equipment for final purification. The demonstrated ability to control the route of neptunium in the solvent extraction processes is an important advantage in selecting the best over-all process for recovery and purification.

\section{DISCUSSION}

The extraction of neptunium in the solvent extraction processes depends upon the processing conditions, and the valence state of neptunium under these processing conditions. Neptunium is extractable in two valence states: $\mathrm{Np}$ (IV), which is about $1 / 5$ as extractable as $\mathrm{Pu}(\mathrm{IV})$; and $\mathrm{Np}(\mathrm{VI})$, which is about as extractable as $\mathrm{Pu}(\mathrm{IV})$. Under normal process conditions, $\mathrm{Fe}(\mathrm{II})$ will reduce $\mathrm{Np}(\mathrm{V})$ and $\mathrm{Np}(\mathrm{VI})$ to $\mathrm{Np}(\mathrm{IV})$ and maintain this valence state; $\mathrm{Np}(\mathrm{VI})$ can be-malntained-by-strong-oxtdizing agents such as $\mathrm{Ce}(\mathrm{IV}), \mathrm{MnO}_{4}{ }^{-}, \mathrm{Cr}_{2} \mathrm{O}_{7}{ }^{2}$, and under special conditions by $\mathrm{HNO}_{2}-\mathrm{HNO}_{3}$. Thus, the problem of extracting neptunium in either solvent extraction process can be resolved into adjusting process conditions to extract either $\mathrm{Np}$ (IV) or $\mathrm{Np}$ (VI), and then taking the necessary measures to maintain neptunium in the proper valence state,

\section{EXPERIMENTAL PROCEDURE}

The solvent extraction process under investigation was operated in miniature mixer-settlers to determine the path of neptunium under varying process conditions. Simliar equipment and run procedures were previously described. $(\theta, 7)$ In these experiments, no significant level of fission products was present, and the effect of the process changes on fission product decontamination was not determined. Two different isotopes of neptunium were used: $\mathrm{Np}^{239}$ in experiments with the Purex process, and $\mathrm{Np}^{237}$ in experiments with the HM process. $\mathrm{Np}^{239}$ was measured analytically with a gamma scintillation spectrometer, and $\mathrm{Np}^{237}$ was measured by standard alpha counting techniques.

To produce the feed solution for studies of the Purex process, $\mathrm{UO}_{3}$ was irradiated for 2 to $10 \mathrm{kwh}$ in the SRL Standard Pile. The $\mathrm{U}^{23 \theta}$ produced by the plie irradiation was allowed to decay to $\mathrm{Np}^{239}$, and the irradiated material was dissolved in nitric acid. Silver lodide was precipitated from this solution to remove the 8 -day $I^{131}$ and to avold interference of the $I^{131}$ gamma with the $\mathrm{Np}^{230}$ gamma during the determination of neptunium. After filtration to remove the AgI precipitate, the solution was adfusted to the proper concentrations of acid and uranium for Purex feed.

Feed for experiments on the HM process was made by dissolving uranyl nitrate and aluminum nitrate in dilute nitric acid and adding a nitric acid solution of $\mathrm{Np}^{237}$. 


\section{PUREX PROCESS}

\section{GENERAL}

In the Purex process at the Savannah River Plant, $\mathrm{Np}^{237}$ is normaliy discharged in the aqueous waste stream (IAW) from the initial mixersettler bank (IA bank) (see Figure 1). Recovery of neptunium from this waste stream can be accomplished by an anion exchange process; however, this waste stream contains virtually all the fission products and requires a maximum effort to decontaminate and purify neptunium by anion exchange. Two methods for improvement of this process were studied: (1) the extraction of the neptunium with uranium in the IA bank to permit the eventual separation from a second solvent extraction cycle waste concentrate by anion exchange; and (2) the accumulation of neptunium in the $1 \mathrm{~A}$ bank by reflux, the periodic removal of neptunium from the bank in the aqueous waste, and recovery of neptunium from this waste stream. The advantage of the first method is that the fission product level is decreased by a factor of about $10^{3}$ before anion exchange processing, thus simplifying the processing required. The second method achieves a separation of neptunium from fission products in the solvent extraction process, and also decreases the volume of solution to be processed by the anion exchange by a factor of 5 to 10 .

\section{EXTRACTION OF $\mathrm{Np}(\mathrm{VI})$ IN THE 1 A BANK}

The extraction of $\mathrm{Np}$ (VI) in the $1 \mathrm{~A}$ bank depends upon oxidizing neptunium to $\mathrm{Np}(\mathrm{VI})$ and adjusting the extractant flow so that $\mathrm{Np}$ (VI) is extracted. The oxidizing agents investigated were nitric acid catalyzed by $\mathrm{HNO}_{2}$, and $\mathrm{Ce}$ (IV). Prior studies at Hanford (1) showed that the addition of $10^{-3} \mathrm{M} \mathrm{HNO}_{2}$ as a catalyst to the extractant stream ( IAX) and elimination of $\mathrm{HNO}_{2}$ from the feed stream (IAF) permitted excellent extraction of neptunium. These results were in accord with the study of Siddall and Dukes(8), who found that low concentrations of $\mathrm{HNO}_{2}$ catalyzed the oxidation of $\mathrm{Np}(\mathrm{V})$ to $\mathrm{Np}(\mathrm{VI})$ but that higher concentrations of $\mathrm{HNO}_{2}$ reduced $\mathrm{Np}(\mathrm{VI})$ to $\mathrm{Np}(\mathrm{V})$. Oxidation by $\mathrm{Ce}(\mathrm{IV})$ was investigated to determine the behavior of $\mathrm{Np}(\mathrm{VI})$ when no $\mathrm{HNO}_{2}$ was present.

In the solvent extraction tests two mixer-settler banks, of 16 and 12 stages, were connected to simulate a 28 -stage $1 \mathrm{~A}$ bank. The organic stream from the $1 \mathrm{~A}$ bank was fed to the center of a 16-stage $1 \mathrm{~B}$ bank and was then stripped in a 16-stage IC bank (Figure 2), as in the normal Purex process. The $I A$ and $2 B$ banks (Figure 2) were operated at $35^{\circ} \mathrm{C}$, and the $\mathrm{IC}$ bank at $45^{\circ} \mathrm{C}$. The process flowsheet for these tests is shown in Table $I$. 
TABLE I

Purex Test Flowsheet

\begin{tabular}{|c|c|c|c|}
\hline Stream & $\begin{array}{l}\text { Relative } \\
\text { Flow }\end{array}$ & $\begin{array}{l}\text { Process } \\
\text { Entry }\end{array}$ & Composition \\
\hline$I A F$ & 100 & $1 A-13$ & $\begin{array}{l}1.5 \mathrm{M} \mathrm{UNH}, 1-2 \mathrm{M} \mathrm{HNO}_{3}, \\
5 \times 10^{5} \gamma \mathrm{c} /(\mathrm{mIn})(\mathrm{ml}) \text { of } \mathrm{Np}^{239}\end{array}$ \\
\hline IAS & 76.5 & $1 A-1$ & $3 \mathrm{M} \mathrm{HNO}$ \\
\hline IAS: & (a) & $1 \mathrm{~A}-27$ & $(b)$ \\
\hline $1 \mathrm{AX}$ & $340-480^{(a)}$ & $1 A-28$ & $30 \% \mathrm{TBP}$ \\
\hline $1 \mathrm{BS}$ & $-83 \cdot 3 \ldots$ & $-1 \mathrm{~B}-16$ & $30 \% \mathrm{TBP}$ \\
\hline $1 \mathrm{BX}$ & 50 & $1 \mathrm{~B}-1$ & $0.1 \mathrm{M} \mathrm{HNO}_{3}, 0.04 \mathrm{M} \mathrm{Fe}\left(\mathrm{SO}_{3} \mathrm{NH}_{2}\right)_{2}$ \\
\hline $10 x$ & 710 & $1 C-1$ & $0.05 \mathrm{M} \mathrm{HNO}_{3}$ \\
\hline
\end{tabular}

The results of these tests are summarized in Table II.

TABLE II

Extraction of Neptunium in Purex Process

\begin{tabular}{|c|c|c|c|c|c|}
\hline \multirow{2}{*}{$\begin{array}{c}\text { IAS' } \\
\text { Composition } \\
\end{array}$} & \multirow{2}{*}{$\begin{array}{r}\text { IAS' } \\
\text { Relative } \\
\text { Flow } \\
\end{array}$} & \multirow{2}{*}{$\begin{array}{c}\text { laX } \\
\text { Relative } \\
\text { Flow }\end{array}$} & \multirow{2}{*}{$\begin{array}{c}\text { Organic } \\
\text { Phase (IAP) } \\
\text { Saturation, } \%\end{array}$} & \multicolumn{2}{|c|}{$\begin{array}{l}\text { Np, \% of Total } \\
\text { In Feed }\end{array}$} \\
\hline & & & & $\underline{I C U}$ & $I \mathrm{AW}$ \\
\hline $0.01 \mathrm{M} \mathrm{NaNO}$ & 37.8 & 378 & 73 & - & $20(a)$ \\
\hline $0.01 \mathrm{M} \mathrm{NaNO}$ & 40 & 400 & 70 & 72 & 28 \\
\hline $0.01 \mathrm{M} \mathrm{NaNO}$ & 44 & 440 & 63 & 93 & 7 \\
\hline $0.01 \mathrm{M} \mathrm{NaNO}$ & 48 & 480 & 58 & 100 & - \\
\hline $0.1 \mathrm{M} \mathrm{Ce}\left(\mathrm{NO}_{3}\right)$ & 21 & 386 & 72 & 100 & - \\
\hline No IAS' Fed & - & 378 & 73 & 4 & $20(a)$ \\
\hline No $1 \mathrm{AS}$, Fed & - & 420 & 66 & 16 & $60(a)$ \\
\hline
\end{tabular}

(a) Neptunium was accumulating in the $1 \mathrm{~A}$ bank by reflux; steady-state conditions were not reached in the end streams. 
The results of the tests with $\mathrm{NaNO}_{2}$ are in agreement with the results obtalned in similar experiments at Hanford: $N p(V I)$ was produced in the IA bank by the $\mathrm{KNO}_{2}$-catalyzed oxidation of $\mathrm{Np}(\mathrm{V})$ by $\mathrm{HNO}_{3}$ and was recovered with the uranium when the saturation of the extractant with uranyl nitrate was about $65 \%$ or less. In the absence of nitrous acid, neptunium extraction was poor because the principal species present were $\mathrm{Np}(\mathrm{V})$ and $\mathrm{Np}(\mathrm{IV})$. The extraction of $\mathrm{Np}(\mathrm{VI})$ with $\mathrm{Ce}(\mathrm{IV})$ as the oxidant indicates clearly that inability to recover $\mathrm{Np}(\mathrm{VI})$ from a saturated (75\%) organic phase was not caused by a low Np(VI) distribution coefficient. Complete recovery was obtained with $\mathrm{Ce}(\mathrm{IV})$ as an oxidizing agent at $72 \%$ saturation; with $\mathrm{HNO}_{2}-\mathrm{HNO}_{3}$ as oxidant, there was essentialiy no extraction of neptunium at $72 \%$ saturation. The probable explanation for this result is that high saturation conditions cause the reflux of $\mathrm{HNO}_{2}$ at the feed point, and $\mathrm{HNO}_{2}$ accumulates until its concentration is high enough to reduce $\mathrm{Np}(\mathrm{VI})$ to $\mathrm{Np}(\mathrm{V})$ by the reaction

$$
2 \mathrm{NpO}_{2}^{++}+\mathrm{HNO}_{2}+\mathrm{H}_{2} \mathrm{O} \longrightarrow 2 \mathrm{NpO}_{2}^{+}+\mathrm{NO}_{3}^{-}+3 \mathrm{H}^{+}
$$

The conditions for extraction of $\mathrm{Np}(\mathrm{VI})$ with $\mathrm{HNO}_{2}$ present requires low enough saturation in the scrub section to prevent reflux of $\mathrm{HNO}_{2}$. $\mathrm{Ce}$ (IV) can be used to recover $\mathrm{Np}(\mathrm{VI})$ with any operable Purex process, since $\mathrm{Ce}(\mathrm{IV})$ oxidizes $\mathrm{HNO}_{2}$ to $\mathrm{HNO}_{3}$, and prevents the accumulation of $\mathrm{HNO}_{2}$. $\mathrm{Np}(\mathrm{VI})$ should be recovered under any process conditions that w11I recover $\mathrm{Pu}(\mathrm{IV})$.

These tests also showed that when neptunium was extracted in the $1 \mathrm{~A}$ bank, it followed the uranium through the IB bank and was stripped with the uranium into the ICU stream. Np(VI) is reduced to $\mathrm{Np}$ (IV) by $\mathrm{Fe}$ (II) in the IB bank. $\mathrm{Np}(\mathrm{IV})$ is sufficlently extractable to be recovered with uranium in the IB bank, but is stripped out of the organic phase with dilute acid in the IC bank. Conditions in the $1 B$ bank can be altered to route the neptunium with the plutonium product stream (IBP); a higher IBX flow and a lower 1BS flow will accomplish this. Under the conditions used in these tests, however, no neptunium was found in the IBP product stream.

\section{REFLUX OF NP(IV) IN THE IA BANK}

A second scheme for neptunium recovery from the Purex process is to reflux neptunium in the $1 \mathrm{~A}$ bank by adjusting conditions to extract $\mathrm{Np}$ (IV) in the extraction section of the bank while maintaining a high uranium saturation in the organic phase to prevent the extraction of $\mathrm{Np}(\mathrm{IV})$ in the scrub section. After the desired amount of neptunium has been accumulated, fission products can be flushed from the bank by feeding an inactive uranyl nitrate solution, and the neptunium can be removed from the bank in either the IAP or the lAW by an appropriate change in oxidation state. Neptunium can then be recovered from the first or second cycle aqueous waste streams by anton exchange. 
The test of this process was made with the basic Purex flowsheet (Table I); a IAX flow of 368 corresponded to $75 \%$ saturation of the organic phase. $\mathrm{Np}$ (IV) was produced in the extraction section by introducing a stream of $0.25 \mathrm{M} \mathrm{Fe}\left(\mathrm{SO}_{3} \mathrm{NH}_{2}\right)_{2}$ (relative flow, 24.2) into the $1 \mathrm{~A}$ bank at stage 20, 7 stages below the feed stage. The process was operated under these conditions unt1l about 70 bank throughputs of the aqueous streams (IAF and IAS) had flowed through the extraction section. Analysis of the end streams at this point showed a loss of $14 \%$ of the neptunlum in the feed to the aqueous waste (1AW) and 4\% to the 1CU. Samples of the organic phase in the 1A bank (Figure 3) showed that neptunium concentrations 120 times greater than feed concentration were reached by the end of the experiment. Sufficient samples were not taken to measure the total neptunium loss during the run, but a linear interpolation indicates a loss of $7 \%$ of the total neptunium to the $1 \mathrm{AW}$, and $2 \%$ to the 1CU. Th1s experiment was performed under conditions of low efflciency for mass transfer; samples showed that the stage-efficlency was about 30-35\%, rather than the normal 85-95\%. W1th normal stage efficiencies, it is probabie that the loss of neptunium to both end streams would be substantially less.

This method for concentrating neptunium requires further laboratory investigation before it is used in a separations plant. The chief items requiring investigation are the effect of $\mathrm{Np}$ (IV) on plutonium recovery, and the effects of $\mathrm{HNO}_{2}$ (Introduced with the feed) on the loss of neptunium. Demonstrations of the methods for removing neptunium from the bank are also desirable. Experiments with this method, in which there is no steady state, are necessarliy long, and development has not been completed. The method is presented in this report because of 1 ts novelty and potential value as a plant process.

\section{HM PROCESS}

\section{GENERAL}

In the HM process (F1gure 4) 75-90\% of the neptunium is normally recovered in the first cycle with the uranium product (ICU) stream. During the purification of the uranium in the second solvent extraction cycle, the neptunium divides, one-third following the uranium into the final uranium product, and two-thirds following the aqueous waste (IDW) stream. The objectives of the laboratory studies were to extract all the neptunium in the $1 \mathrm{~A}$ bank, and to direct the extracted neptunium through solvent extraction to a single stream. To achleve these objectives, the first cycle required modification to increase the extraction of neptunium, and a further modification of the process was necessary, elther to partition neptunium from uranium in the first cycle or to divert the neptunium in the second cycle so that it followed either the lDW stream or the uranium product. A restriction on the possible process changes was that process modifications should not prevent the removal of plutonium from uranlum in both cycles of solvent extraction. A variety of 
tests were made, and the success of most of these tests allows considerable cholce of a method for neptunium recovery from the HM process.

\section{EXTRACTION OF NEPTUNIUM IN THE 1A BANK}

The feed (IAF) stream to the IA bank contains Np, probably as a mixture of $\mathrm{Np}(\mathrm{VI})$ and $\mathrm{Np}(\mathrm{V})$. The scrub section (IAS) contains Fe(II) to reduce $\mathrm{Pu}($ IV) to the inextractable $\mathrm{Pu}$ (III) and permit 1ts separation from uranium. The reducing conditions assure that $\mathrm{Np}$ (IV) will be the predominant species in the organic (IAP) stream leaving the bank. Conditions were tested for the extraction of either Np(VI) or NP(IV) in the $1 \mathrm{~A}$ bank. The tests involved modifications of the standard HM process flowsheet (Table III) in minlature mixer-settler equipment.

\section{TABLE III}

HM Flowsheet, 1A Bank

\begin{tabular}{|c|c|c|}
\hline Stream & $\begin{array}{l}\text { Relative } \\
\text { Flow }\end{array}$ & Composition \\
\hline $1 \mathrm{AF}^{(\mathrm{a})}$ & 100 & $\begin{array}{l}1.2 \mathrm{M} \mathrm{Al}\left(\mathrm{NO}_{3}\right)_{3}, 0.5 \mathrm{M} \mathrm{HNO} \\
2.9 \mathrm{~g} \mathrm{U} / 1,10 \mathrm{mg} \mathrm{Np} / 1\end{array}$ \\
\hline $\operatorname{IAS}(a)$ & 35 & $1.2 \mathrm{MAI}\left(\mathrm{NO}_{3}\right)_{3}, \mathrm{pH} 1.3$ \\
\hline$I \mathrm{AX}$ & 210 & 2.5\% TBP in "Ultrasene" \\
\hline
\end{tabular}

The valence of neptunium was controlled with appropriate oxidizing and reducing agents - Fe(II) to produce $\mathrm{Np}(\mathrm{IV}), \mathrm{Ce}(\mathrm{IV})$ to produce $\mathrm{Np}(\mathrm{VI})$. The tests with $\mathrm{Np}$ (IV) were successful in extracting most of the neptunium, and in the tests with Np(VI) virtually all the neptunium was extracted. Results are shown in Table IV, and stage profiles for the neptuntum concentration in the organic phase are shown in Figures 5 and 6 .

\section{TABIE IV}

Extraction of Neptunium in IA Bank in HM Process

\begin{tabular}{|c|c|c|c|c|}
\hline $\begin{array}{c}\text { Oxidizing or Reducing } \\
\text { IAF }\end{array}$ & $\begin{array}{c}\text { Composition } \\
\text { IAS }\end{array}$ & $\begin{array}{l}\text { Temp. } \\
{ }^{\circ} \mathrm{C} \\
\end{array}$ & $\frac{N p, \% \text { of Total }}{\underline{I A W}}$ & $\frac{\text { In Feed }}{1 \mathrm{AP}}$ \\
\hline - & $0.04 \mathrm{M} \mathrm{Fe}\left(\mathrm{SO}_{3} \mathrm{NH}_{2}\right)_{2}$ & 45 & 40 & 60 \\
\hline $0.01 \mathrm{M} \mathrm{Fe}\left(\mathrm{SO}_{3} \mathrm{NH}_{2}\right)_{2}$ & $0.01 \mathrm{M} \mathrm{Fe}\left(\mathrm{SO}_{3} \mathrm{NH}_{2}\right)_{2}$ & 30 & 12 & 88 \\
\hline $0.01 \mathrm{M} \mathrm{Fe}\left(\mathrm{SO}_{3} \mathrm{NH}_{2}\right)_{2}$ & $0.01 \mathrm{M} \mathrm{Fe}\left(\mathrm{SO}_{3} \mathrm{NH}_{2}\right)_{2}$ & 52 & 28 & 72 \\
\hline $0.03 \mathrm{M} \mathrm{Ce}(\mathrm{IV})$ & - & 52 & $<2.5$ & $\sim 100$ \\
\hline $0.0003 \mathrm{M} \mathrm{Ce}(\mathrm{IV})$ & $0.04 \mathrm{M} \mathrm{Fe}\left(\mathrm{SO}_{3} \mathrm{NH}_{2}\right)_{2}$ & 50 & 45 & 55 \\
\hline
\end{tabular}


Tests showed that extraction of $\mathrm{Np}$ (IV) was improved by adding Fe(II) to the feed solution, presumably because the rate of reduction of $\mathrm{Np}(\mathrm{V})$ by $\mathrm{Fe}$ (II) in the bank was not rapid enough to prevent loss to the aqueous waste. A test with $\mathrm{Ce}$ (IV) in the feed and $\mathrm{Fe}$ (II) in the IAS gave identical results as would be predicted considering that $\mathrm{Np}(\mathrm{VI})$ must be reduced through $\mathrm{Np}(\mathrm{V})$ to $\mathrm{Np}(\mathrm{IV})$ for its recovery. $\mathrm{Np}$ (IV) distribution coefficients of about 0.6 in the extraction section of the bank (stages 8 to 16 ) and 0.18 or greater in the scrub section (stages 1 to 8 ) were measured in the run at $52^{\circ} \mathrm{C}$; these are consistent with the observed losses.

When Ce(IV) was used as the oxldant, the extraction of $N p$ (VI) in the IA bank was essentially quantitative; distribution coefficlents for $\mathrm{Np}$ (VI) were greater than one throughout the bank. However, these conditions cannot be applied to the HM process without other changes to prevent the recovery of plutonium with uranium.

Increasing the temperature to $52^{\circ} \mathrm{C}$, when $\mathrm{Fe}$ (II) was added-to-both the IAS and IAF, decreased the extraction of Np(IV). Distribution measurements showed an increase in the extraction of $\mathrm{Np}$ (IV) from synthetic feed solution as the temperature was increased, but there was also a decrease in the extraction from the scrub (IAS) solution (Figure 7). The distribution coefficient for $N$ (IV) from IAS solution was obtained by extrapolation of data obtained at lower temperatures and from the distribution coefficient obtained from the minlature mixer-settler run at $52^{\circ} \mathrm{C}$. The extrapolation is shown in Figure 8. The distribution coefficient of 0.09 at $60^{\circ} \mathrm{C}$ is in accord with the extraction of neptunium that was observed during a plant test of operation at $60^{\circ} \mathrm{C}$.

To permit calculation of the effect of process variations without repeated miniature mixer-settler runs, distribution coefficients for $\mathrm{Np}$ (IV) were measured in the laboratory under conditions applicable to the HM process. These data are shown in Figures 7 through 12.

It was concluded that increased extraction of $\mathrm{Np}$ (IV) in the IA bank can be achieved by adding Fe(II) to the feed solution and by increasing the flow of solvent or the concentration of TBP in the solvent. The measured distribution coefficients of $\mathrm{Np}$ (IV) between aluminum nitrate solutions and 2-3.5\% TBP indicate that a 30\% increase in the flow of the solvent ( $1 \mathrm{AX}$ ) or a $30 \%$ increase in the TBP concentration should give essentialiy $100 \%$ extraction of $\mathrm{Np}$ (IV).

\section{PARTITION OF NEPTUNIUM FROM URANIUM IN THE IB BANK}

The partitioning of extracted neptuntum from uranium in a IB (partition) bank depends upon providing extraction conditions in the bank to retain uranium in the solvent and to strip neptunium from the solvent into the aqueous phase. The distribution coefficients of uranium and $\mathrm{Np}(\mathrm{IV})$ between $4 \mathrm{M} \mathrm{HNO}_{3}$ and $2.5 \% \mathrm{TBP}$ are 1.3 and $0.04,(8)$ respectively, Indicating that a satisfactory partition could be obtained. Additional distribution data for uranium, showing the effects of $\mathrm{HNO}_{3}, \mathrm{TBP}$, and temperature are shown in Figures 13, 14, and 15. 
TABLE V

Partition of $\mathrm{Np}$ (IV) from Uranium in IB Bank

\begin{tabular}{lcl} 
Stream & Flow $(I \mathrm{AF}=100)$ & \multicolumn{1}{c}{ Composition } \\
IAP (organic stream & $210-270$ & $\begin{array}{l}2.5 \% \mathrm{TBP}, 1.5 \mathrm{~g} / \mathrm{I} \mathrm{U}, \\
\text { from IA bank) }\end{array}$ \\
IBX & 70 & $5 \mathrm{mg} / \mathrm{I} \mathrm{Np}$ \\
IBS & 250 & $4 \mathrm{M} \mathrm{HNO}$
\end{tabular}

In miniature mixer-settler tests, Table $V, N p$ (IV) was successfully stripped into $4 \mathrm{M} \mathrm{HNO}_{3}$ and separated from uranium. The loss of neptunium to the uranium (organic) stream was less than $2 \%$ at $35^{\circ} \mathrm{C}$, and the aqueous neptunium product stream contained less than $0.07 \%$ of the total uranium.

When $\mathrm{Np}(\mathrm{VI})$ was extracted in the IA bank, the extracted $\mathrm{Np}(\mathrm{VI})$ was successfully partitioned from uranium in the $1 \mathrm{~B}$ bank by adding $0.1-0.2 \mathrm{M} \mathrm{NaNO} 2$ to the $1 \mathrm{BX}$ to reduce $\mathrm{Np}(\mathrm{VI})$ to the Inextractable $\mathrm{Np}(\mathrm{V})$. Because $\mathrm{HNO}_{2}$ is extracted into the solvent, it is probable that a smaller quantity of $\mathrm{NaNO}_{2}$ added near the feed stage of the bank would have been fust as effective. Under the conditions tested, about 97\% of the $\mathrm{Np}(\mathrm{VI})$ was reduced and recovered in the aqueous stream. W1th no sodium nitrite added, nearly all the neptunium followed the uranium stream through the $I B$ bank.

\section{EXTRACTION OF NEPTUNIUM IN THE ID BANK}

The extraction of neptunium with the uranium in the ID bank was tested with the intent of permitting the later separation of neptunium from the uranium product by cation exchange. The easiest method for recovering neptunium depends upon maintaining neptunium as $\mathrm{Np}(\mathrm{VI})$; the extraction of Np(VI) by $7.5 \%$ TBP is sufficient (aistribution coefficient is 1.3 in $3 \mathrm{M} \mathrm{HNO}_{3}$ ) to assure virtually complete extraction. The extraction of $\mathrm{Np}(\mathrm{VI})$ was tested in minlature mixer-settlers; $\mathrm{Ce}$ (IV) and $\mathrm{HNO}_{2}$ were used to maintain $\mathrm{Np}$ (VI). Extraction was quantitative when $\mathrm{Ce}$ (IV) was used as an oxldant, but was only about $85 \%$ when $\mathrm{HNO}_{2}$ was used.

The feed solution for the mixer-settler tests contalned $3.2 \mathrm{~g} \mathrm{U} / 1$, 4.1 $\mathrm{M} \mathrm{HNO}_{3}$ and about $10^{4} \alpha \mathrm{d} /(\mathrm{mln})(\mathrm{ml})$ of $\mathrm{Np}^{237}$. The mixer-settler experiments were performed by operating the process with $\mathrm{Ce}$ (IV) as an oxidant until steady-state concentrations of neptunium were reached in the end streams, sampling the organic phase in all stages of the ID bank, and then operating to steady-state conditions with nitrous acid as an oxidant. The flowsheets for the tests are given in Table VI. 


\section{TABLE VI}

Test Flowsheet, ID Bank

\begin{tabular}{|c|c|c|c|c|}
\hline Stream & $\begin{array}{l}\text { Relative } \\
\text { Flow } \\
\end{array}$ & $\begin{array}{l}\text { Enters ID Bank } \\
\text { at Stage } \\
\end{array}$ & Composition & $\begin{array}{l}\text { Temp. } \\
{ }^{\circ} \mathrm{C} \\
\end{array}$ \\
\hline IDF & 200 & 8 & $\begin{array}{l}3.2 \mathrm{~g} \mathrm{U} / 1,4.2 \mathrm{M} \mathrm{HNO} \\
1.1 \times 10^{4} \propto \mathrm{d} /(\mathrm{mIn})(\mathrm{ml}) \text { of }\end{array}$ & $\mathrm{Np}(V)$ \\
\hline IDS & 48 & 1 & $1.2 \mathrm{M} \mathrm{HNO}_{3}$ & \\
\hline$I D X$ & 286 & 16 & $7.5 \%$ T'BP & \\
\hline
\end{tabular}

Tests with

Oxidizing Agent

$\begin{array}{rllll}\text { Test No. } 1 & 26 & 9 & 0.2 \mathrm{M} \mathrm{Ce}(\mathrm{IV}), 4.2 \mathrm{M} \mathrm{HNO} & 35 \\ 2 & 28.6 & 14 & 0.005 \mathrm{M} \mathrm{NaNO}_{2},-4.2 \mathrm{M}-\mathrm{HNO}_{3} & 42 \\ 3(\mathrm{a}) & 28.6 & 14 & 0.01 \mathrm{M} \mathrm{NaNO}, 4.2 \mathrm{M} \mathrm{HNO} \mathrm{HNO}_{3} & 35\end{array}$

(a) IDS $2 \mathrm{M} \mathrm{HNO}_{3}$

The test of $\mathrm{Ce}$ (IV) as an oxidizing agent was quite successful; loss of neptunium to the IDW was below detectable limits. Supplementary experiments indicated that $10^{-3} \mathrm{M} \mathrm{Ce}$ (IV) is sufficient to stabilize $\mathrm{Np}(\mathrm{VI})$ long enough to permit 1 ts extraction in the $1 \mathrm{D}$ bank. Distribution data are shown in Figure 16 and a stage profile for Np(VI) in the organic phase is shown in Figure 17.

The oxidation of $\mathrm{Np}(\mathrm{V})$ to $\mathrm{Np}(\mathrm{VI})$ by $\mathrm{HNO}_{2}-\mathrm{HNO}_{3}$ was not as successful; $85 \%$ recovery of neptunium was obtained with concentrations of $10^{-3} \mathrm{M}$ and $5 \times 10^{-4} \mathrm{M} \mathrm{HNO}_{2}$ in the organic phase. Stage samples (Figures 18 and 19) showed that there was some reflux of neptunium in the organic phase. The poorer recovery of neptunium is belleved to be the result of the slow rate of oxidation of $\mathrm{Np}(\mathrm{V})$ to $\mathrm{Np}(\mathrm{VI})$ by $\mathrm{HNO}_{2}-\mathrm{HNO}_{3}$; the half-time for the oxidation is about 7 minutes at $35^{\circ} \mathrm{C}$ in $3 \mathrm{M} \mathrm{HNO}_{3}(\mathrm{~B})$. From this rate and a residence time of 3 minutes per stage, a pseudoextraction factor of 1.4 was calculated. The predicted neptunium loss for an extraction factor of 1.4 is about 13\%, in reasonable agreement with the experimental loss of 15\%. Assuming this explanation is correct, the rate of oxidation could be increased by raising the operating temperature, thus leading to increased recovery.

This processing scheme was not constdered for use in the Plant because other factors led to the need for increased separation of plutonium from uranium in the ID bank, and the addition of oxidants to the bank precludes this separation. It is probable that cation exchange separation of neptunium from urantum would also separate plutonium from uranium. 
The normal ID bank flowsheet uses reducing conditions to complete the partition of plutonium from the recovered uranium. Under such conditions, neptunium is present as $\mathrm{Np}$ (IV). The effect of scrub (1DS) acidity on the behavior of neptunium in the ID bank was calculated from extrapolated distribution data. The calculated results agreed well with data obtained in plant operation and indicate that a satisfactory partition of neptunium from uranium can be obtalned in the ID bank at low scrub (IDS) acldity. The flowsheet used for these calculations was as follows.

\begin{tabular}{crl} 
Stream & Relative Flow & Composition \\
\cline { 1 - 2 } IDF & 100 & $4.1 \mathrm{M} \mathrm{HNO}_{3}$ \\
IDS & 56 & $0.8-1.5 \mathrm{M} \mathrm{HNO}_{3}$ \\
IDX & 330 & $7.5 \% \mathrm{TBP}$
\end{tabular}

The calculated recovery of neptunium at three different IDS acidities is tabulated in Table VII below, together with representative data from the plant operation.

\section{TABLE VII}

Partition of $\mathrm{Np}(\mathrm{IV})$ from Uranium in ID Bank

\begin{tabular}{|c|c|c|c|c|}
\hline $\begin{array}{c}\text { IDS Acld } \\
\text { Concentration, M }\end{array}$ & $\begin{array}{l}\text { Per cent of } \\
\text { In Aqueous }\end{array}$ & $\begin{array}{l}\text { Total Np } \\
\text { Waste }\end{array}$ & $\begin{array}{l}\text { Per cent of } \\
\text { In Uranium }\end{array}$ & $\begin{array}{l}\text { Total Np } \\
\text { Product }\end{array}$ \\
\hline & Calc. & Plant & Calc. & Plant \\
\hline 0.80 & 99.5 & $96(a)$ & 0.5 & $4(a)$ \\
\hline 1.2 & 77 & 70 & 23 & 30 \\
\hline 1.5 & 23 & - & 67 & - \\
\hline
\end{tabular}

(a) This value may not represent steady-state operation; the trend of the data was toward a lower percentage of neptunium in the uranium product.

The calculations indicated a substantial reflux of neptunium at about the middle of the ID bank with the peak concentration at the seventh stage from product end of the bank (F1gure 20). The inventory of neptunium in the bank, in both phases, is 3-to-7-fold greater than the feed concentration.

These calculations show that relatively minor changes in the flowsheet could achieve an adequate partition of neptunium from the uranium, and indicate that the conditions could be adjusted (higher acidity in feed, higher solvent flow) for essentially complete extraction of neptunium. The changes required to partition neptunium from uranium, 
according to plant experlence, would tend to Improve the decontamination performance and increase the inventory of uranium in the bank; the process changes required to extract neptunium with the uranium would tend to decrease both the decontamination performance and the bank inventory of uranium. The usefulness of either partition or extraction in the ID bank depends upon the other constraints placed upon the process, but both methods have the advantage of achieving the goal of removing neptunium without requiring an expenditure for new capltal equipment.

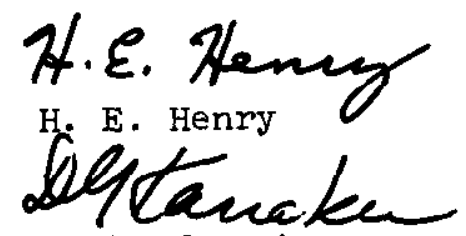

D. G. Karraker 


\section{BIBLIOGRAPHY}

I. Benedict, G. E., G. L. Richardson, and T. R. McKenzie. "Recovery of Neptunium in Solvent Extraction Processes". Abstracts of Papers, p. 43M. 138th Meeting of American Chemical Soc1ety, New York, September 11-16, 1960, Paper 119, D1v1s1on of Industrial and Engineering Chem.

2. Chemistry Division Semi-annual Progress Report for Period Ending June 20, 1955. Oak Ridge National Laboratory, Oak Ridge, Tenn. AEC Research and Development Report ORNL-1940, 94 pp. (October 1955) (declassified March 2, 1957).

3. Chemistry Division Semi-annual Progress Report for Period Ending December 20, 1955. Oak Ridge National Laboratory, Oak RIdge, Tenn. AEC Research and Development Report ORNL-2046, 94 pp. (April 1956) (declassified March 2, 1957).

4. Lewis, W. H. "Americlum and Neptunium Recovery Processes". Proc. U. N. Intern. Conf. Peaceful Uses Atomic Energy. 2nd, Geneva, I7, $236-44$ (1958). $\mathrm{P} / 537$

5. Chemical Technology Division Monthly Progress Report for July 1957. Oak Ridge National Laboratory, Oak Ridge, Tenn. AEC Research and Development Report ORNL-2385, $68 \mathrm{pp}$. (November 1957)(Confident1a1).

6. Karraker, D. G. A One-Cycle Purex Process. E. I. du Pont de Nemours and Co., Savannah R1ver Laboratory, A1ken, S. C. AEC Research and Development Report DP-317, 31 pp. (1958)(Conf1dent1a1).

7. Groh, H. J., et al. Recovery of U from Irradiated U-AI Alloy (title classified Secret). E. I. du Pont de Nemours and Co., Savannah River Laboratory, Alken, S. C. AEC Research and Development Report DP-337, 36 pp. (1959)(Secret).

8. Siddall, T. H. and E. K. Dukes. "Kinetics of $\mathrm{HNO}_{2}$ Catalyzed Oxidation of Neptunium (V) by Aqueous Solutions of Nitric Acid". J. Am. Chem. Soc. 81, 790-4 (1959).

9. Geary, N. R. Collected Partition Data for Tri-butyl Phosphate. United Kingdom Atomic Energy Authority, Windscale Works, Lancashire, Eng. Research and Development Report IGR-R/8142, 54 pp. (August 1955). 


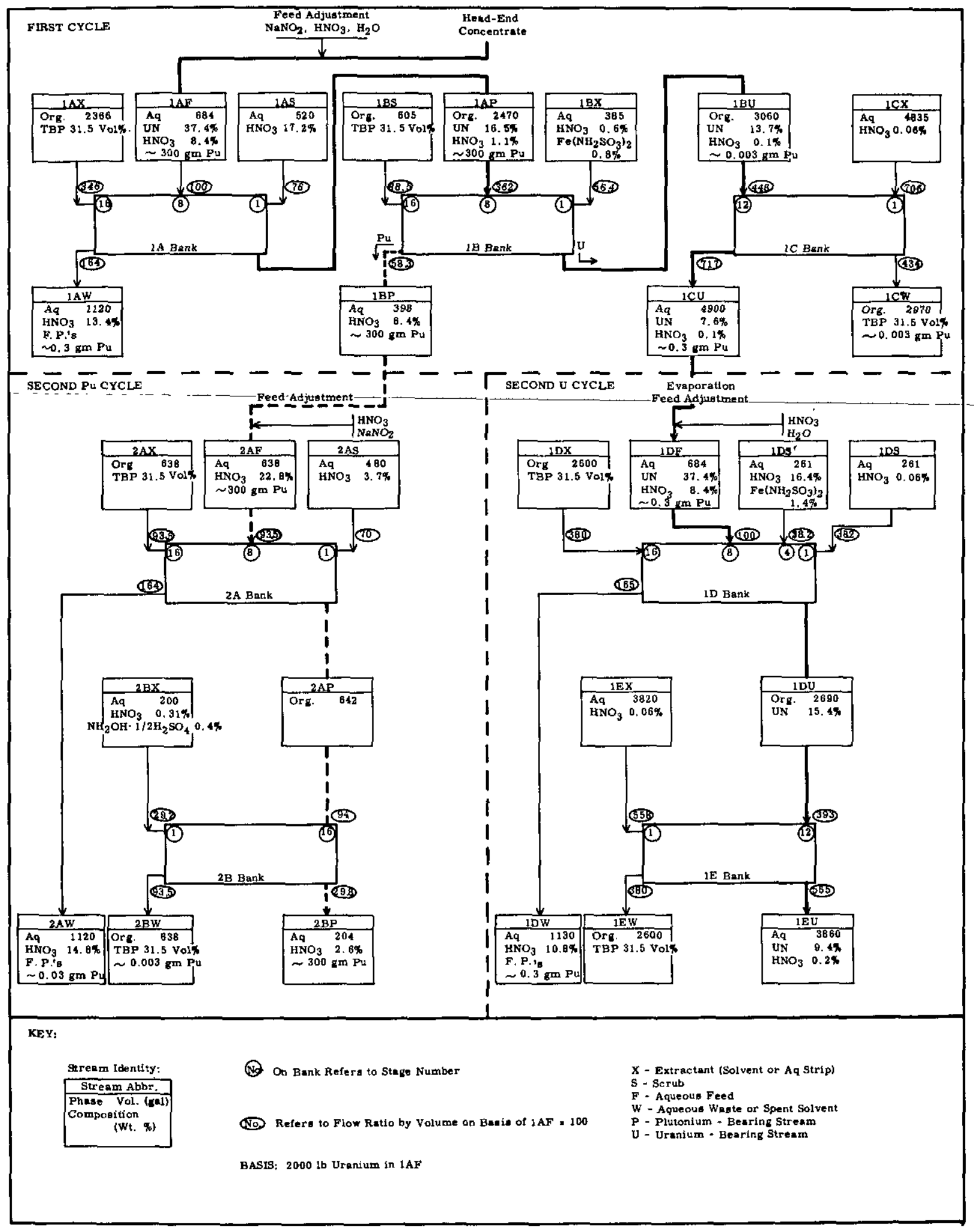

FIG. I OUTLINE OF SRP PUREX PROCESS 


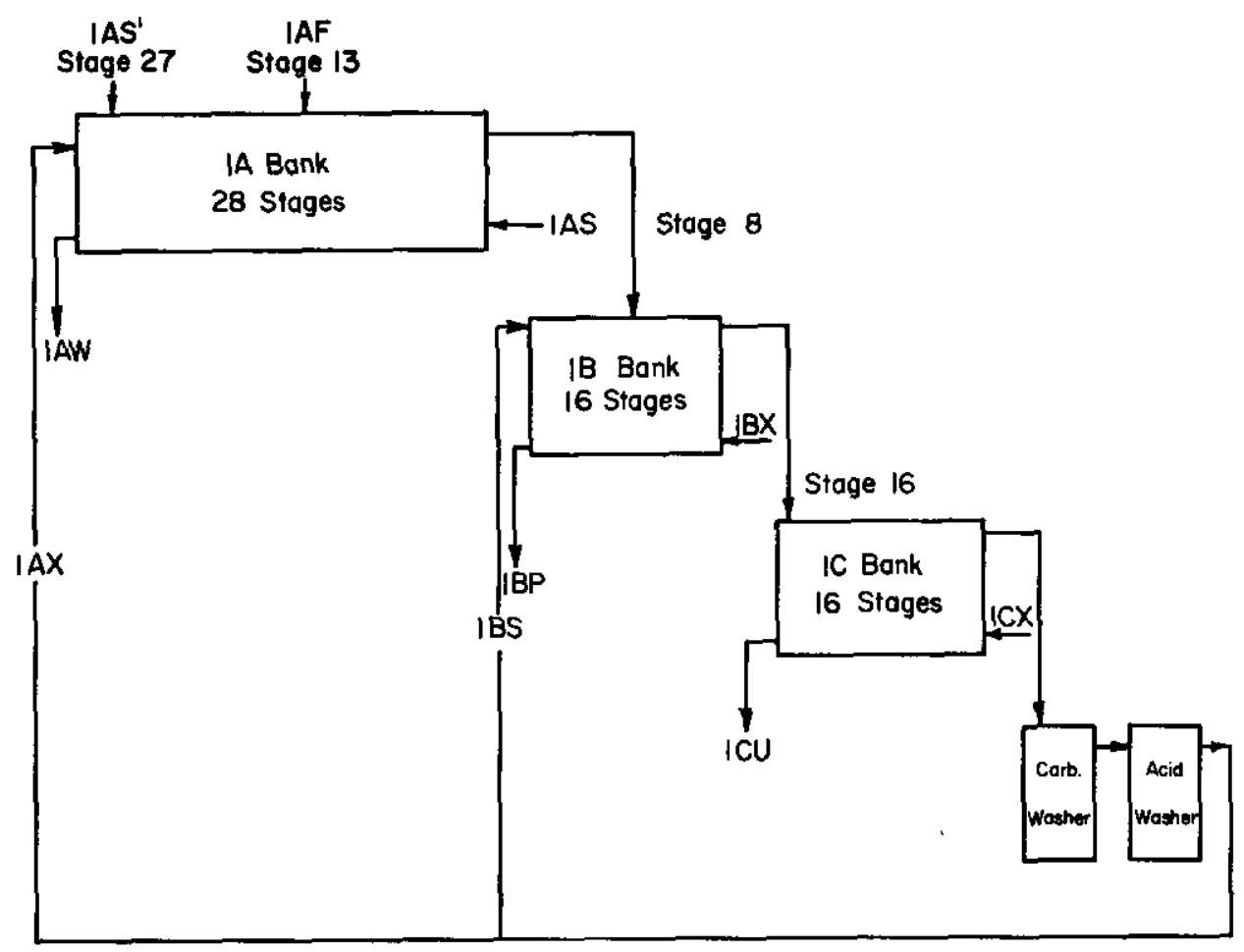

FIG. 2 FLOW DIAGRAM FOR PUREX TEST FLOWSHEET

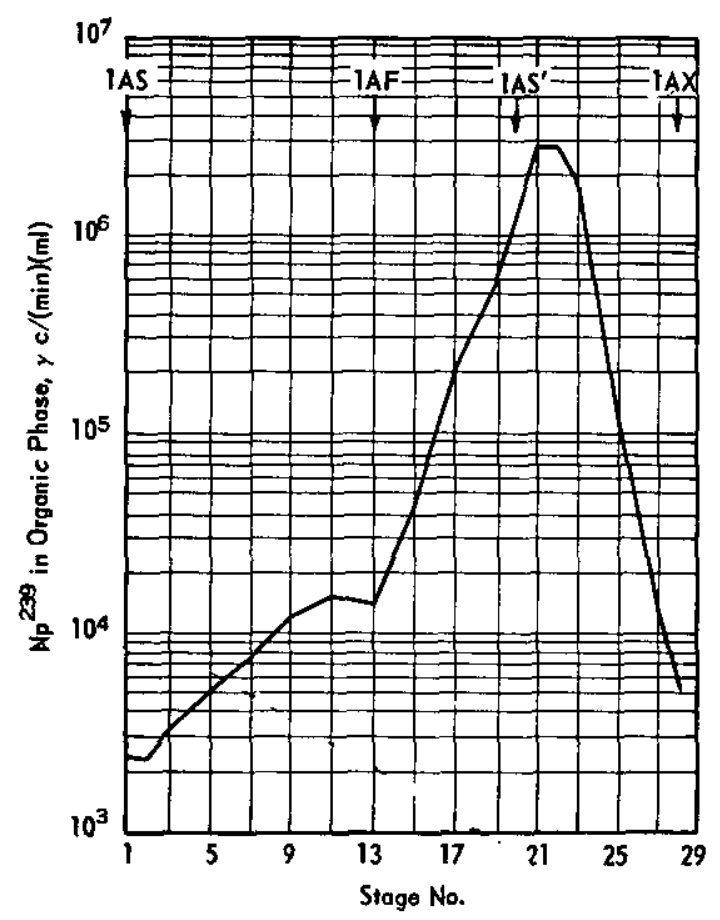

FIG. 3 STAGE PROFILE OF NEPTUNIUM IN ORGANIC PHASE OF IA BANK, PUREX PROCESS 

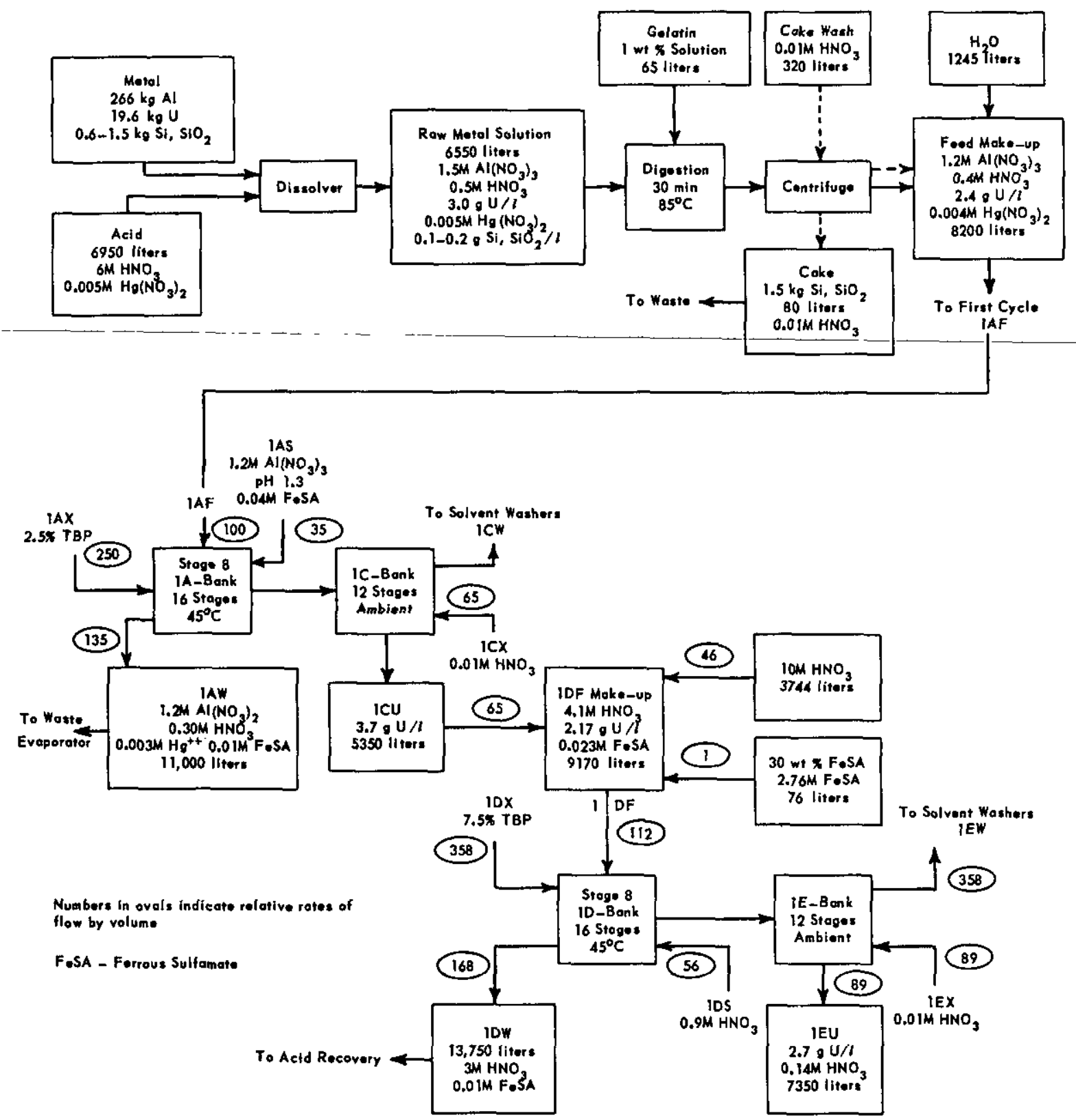

FIG. 4 OUTLINE OF HM PROCESS 


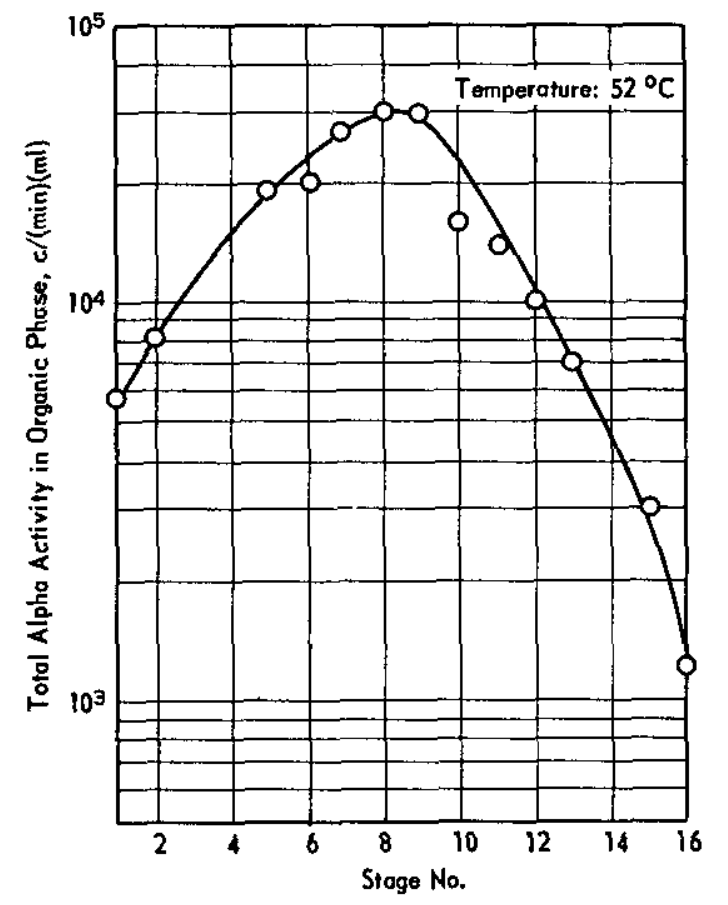

FIG. 5 STAGE PROFILE OF NP(iV) IN ORGANIC PHASE OF IA BANK, HM PROCESS

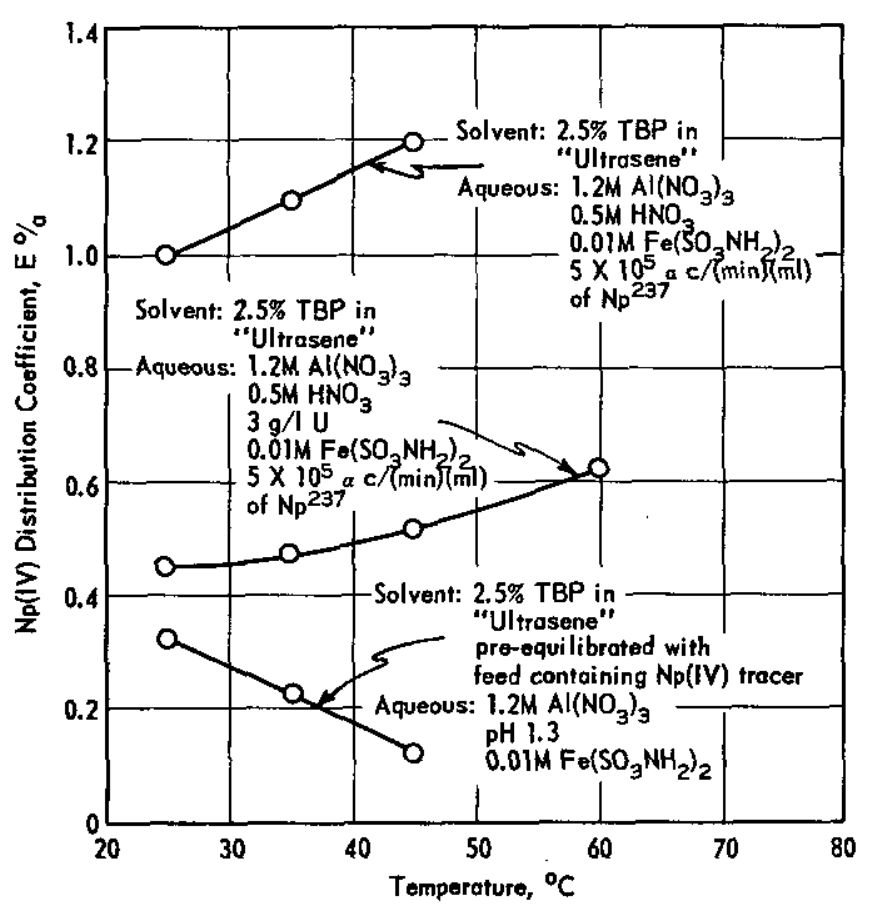

FIG. 7 EFFECT OF TEMPERATURE ON DISTRIBUTION OF NP(IV), HM PROCESS

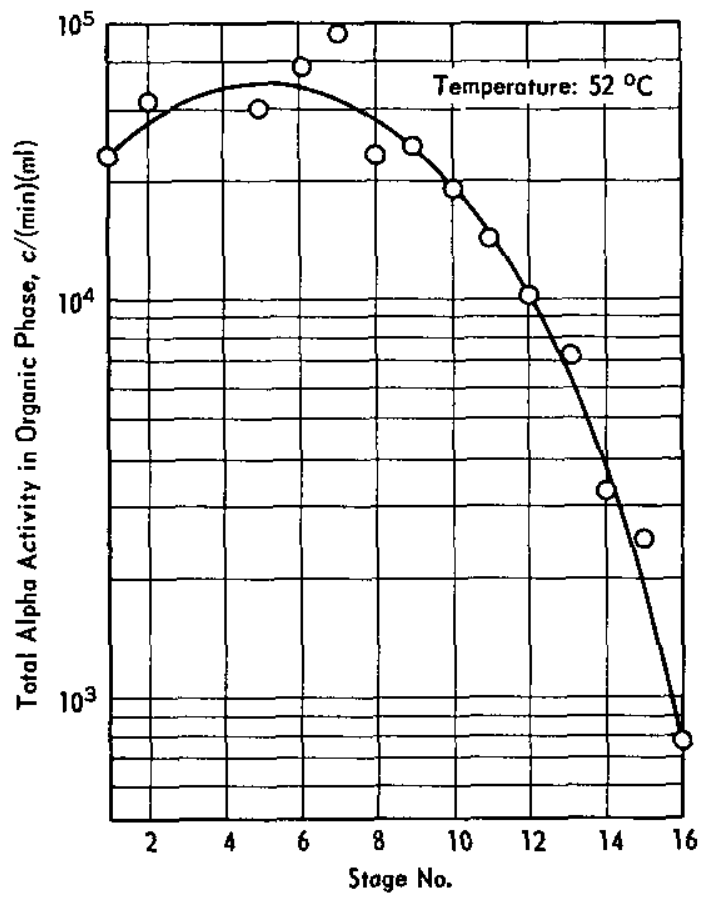

FIG. 6 STAGE PROFILE OF NP(VI) IN ORGANIC PHASE OF IA BANK, HM PROCESS

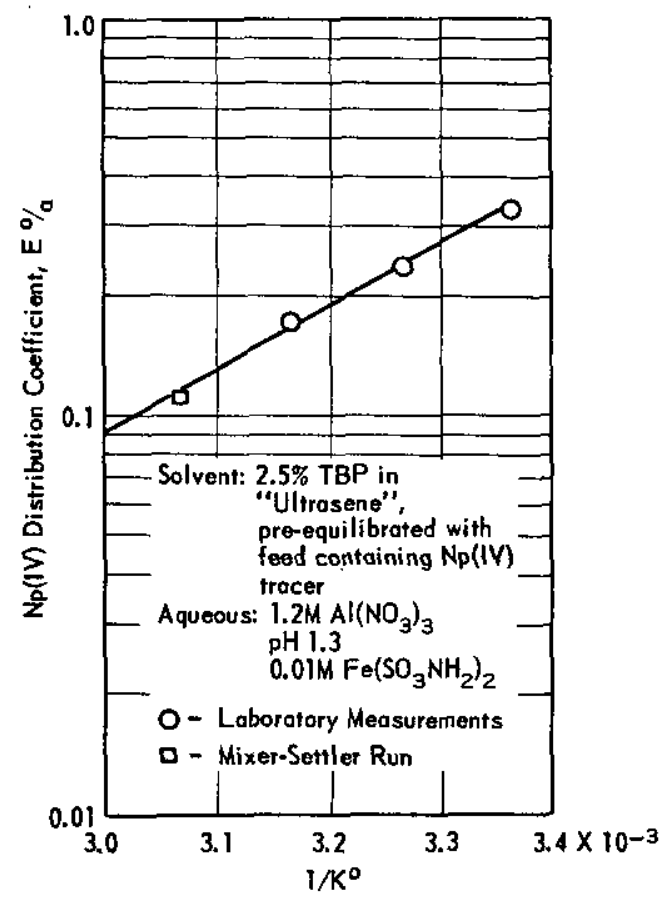

FIG. 8 EXTRAPOLATION OF DISTRIBUTION DATA FOR NP(IV), HM PROCESS 


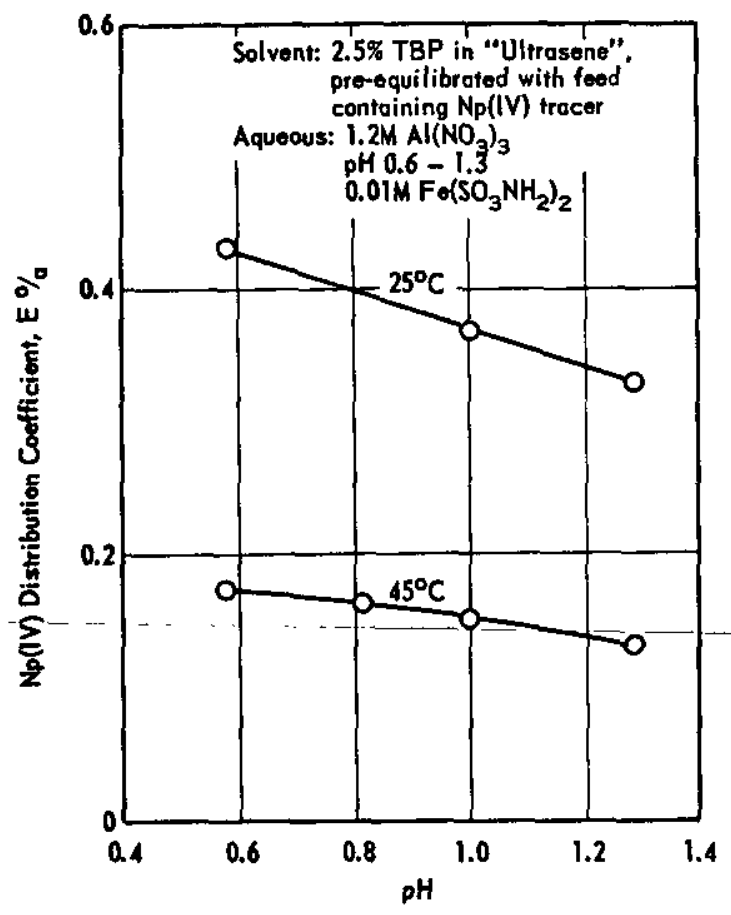

FIG. 9 EFFECT OF PH ON DISTRIBUTION OF NP(IV), HM PROCESS

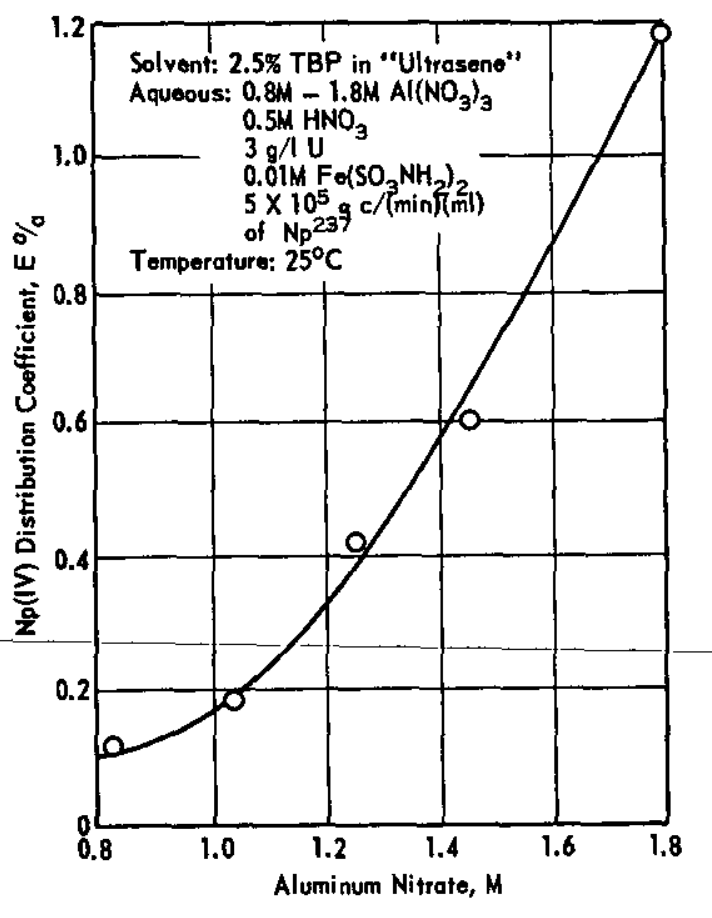

FIG. 10 EFFECT OF ALUMINUM NITRATE ON DISTRIBUTION OF NP(IV), HM PROCESS

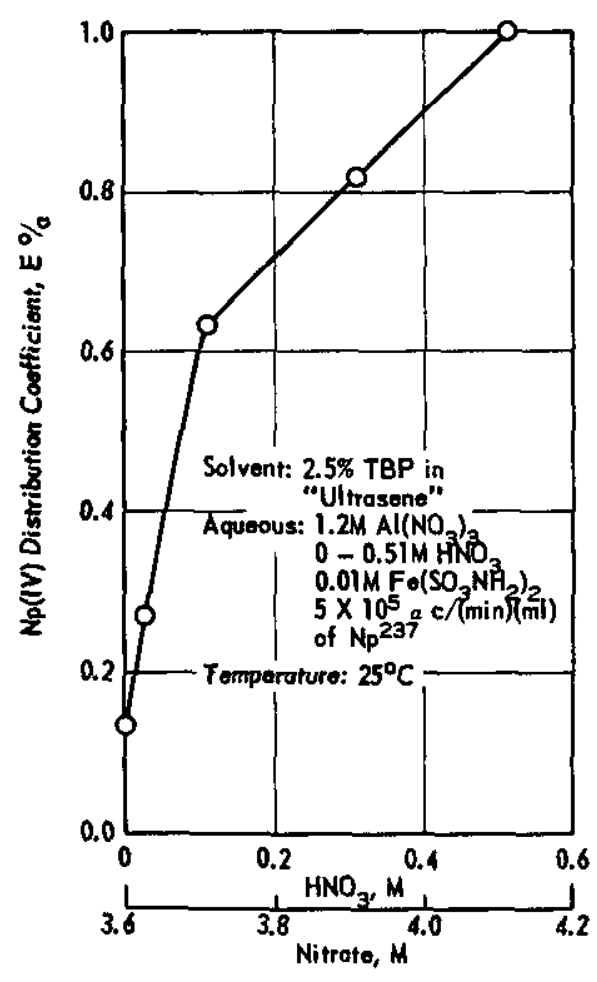

FIG. 11 EFFECT OF NITRIC ACID (NITRATE) ON DISTRIBUTION OF Np(IV), HM PROCESS

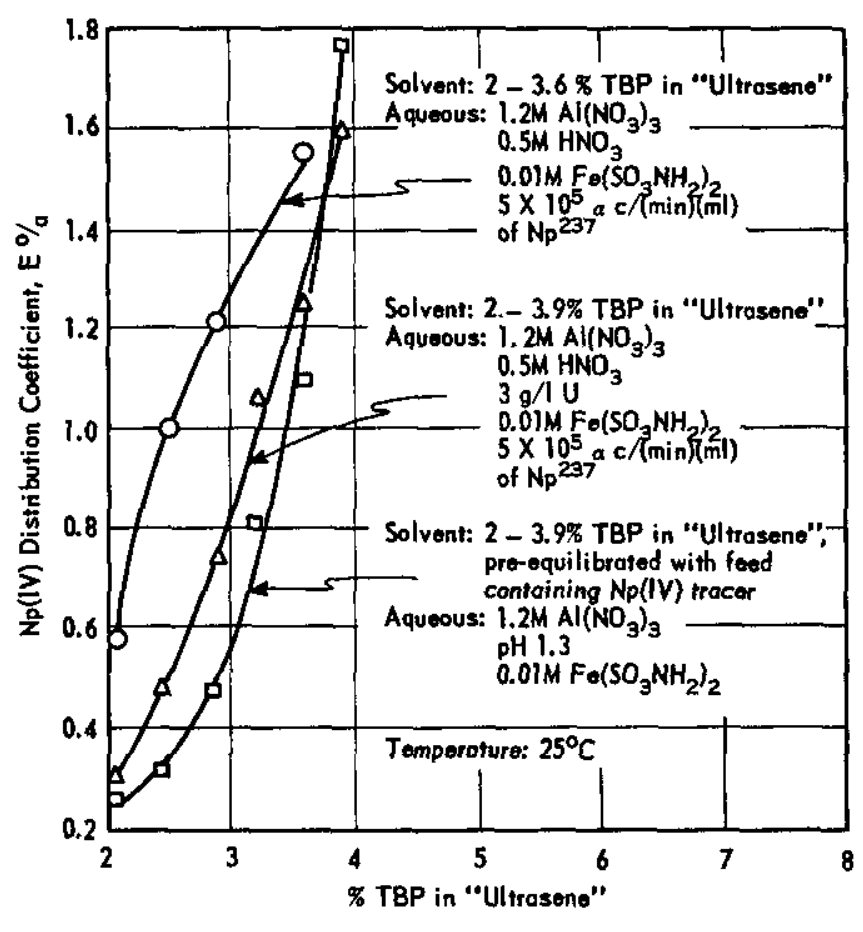

FIG. 12 EFFECT OF TBP ON DISTRIBUTION OF Np(IV), HM PROCESS 


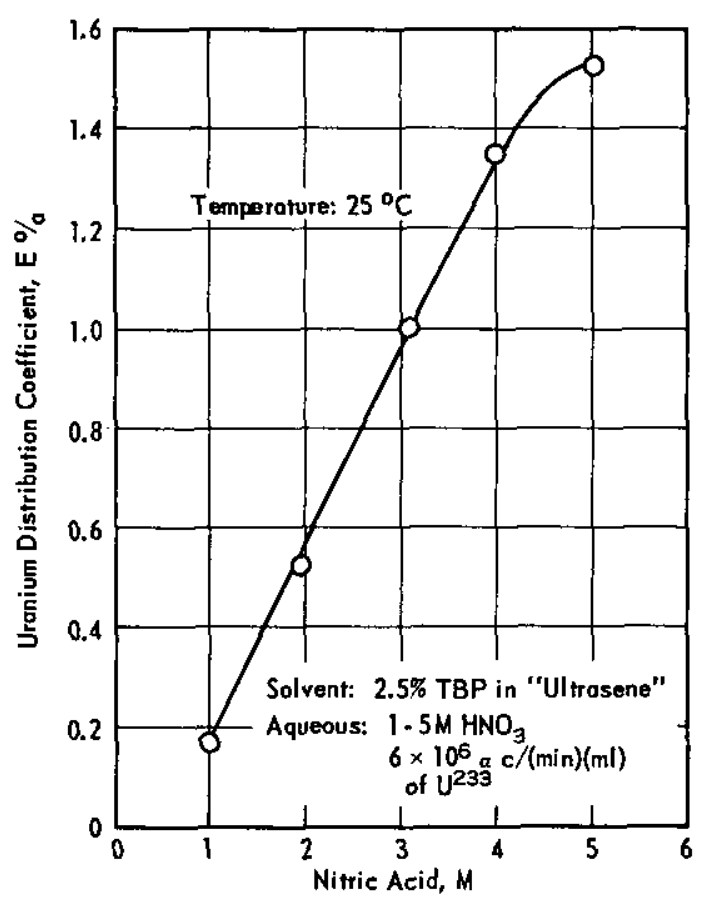

FIG. 13 EFFECT OF NITRIC ACID ON DISTRI BUTION OF URANIUM, HM PROCESS

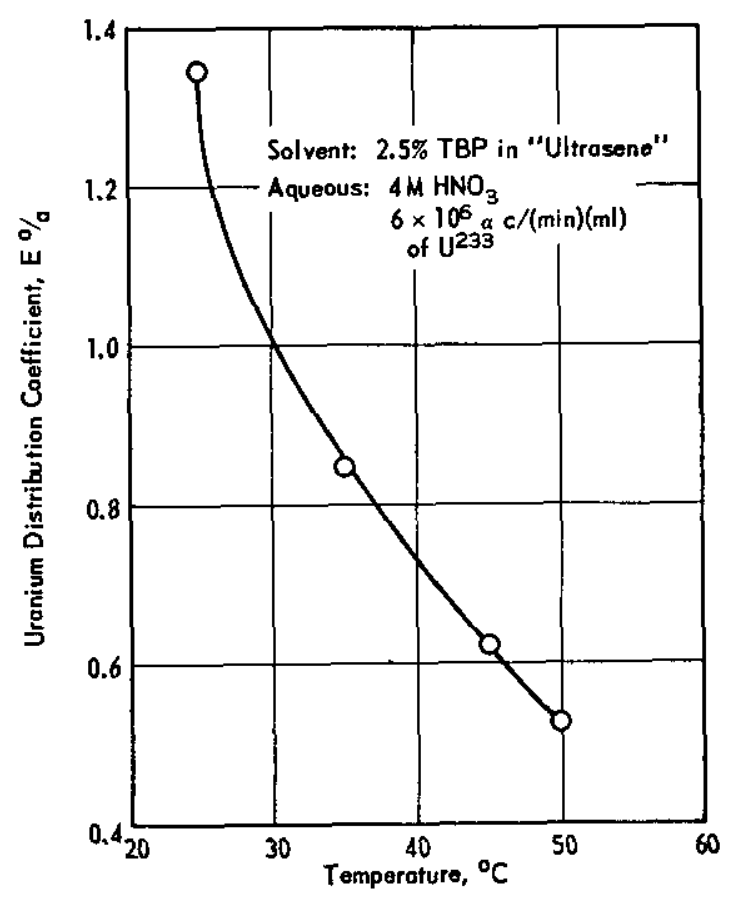

FIG. 15 EFFECT OF TEMPERATURE ON DISTRIBUTION OF URANIUM, HM PROCESS

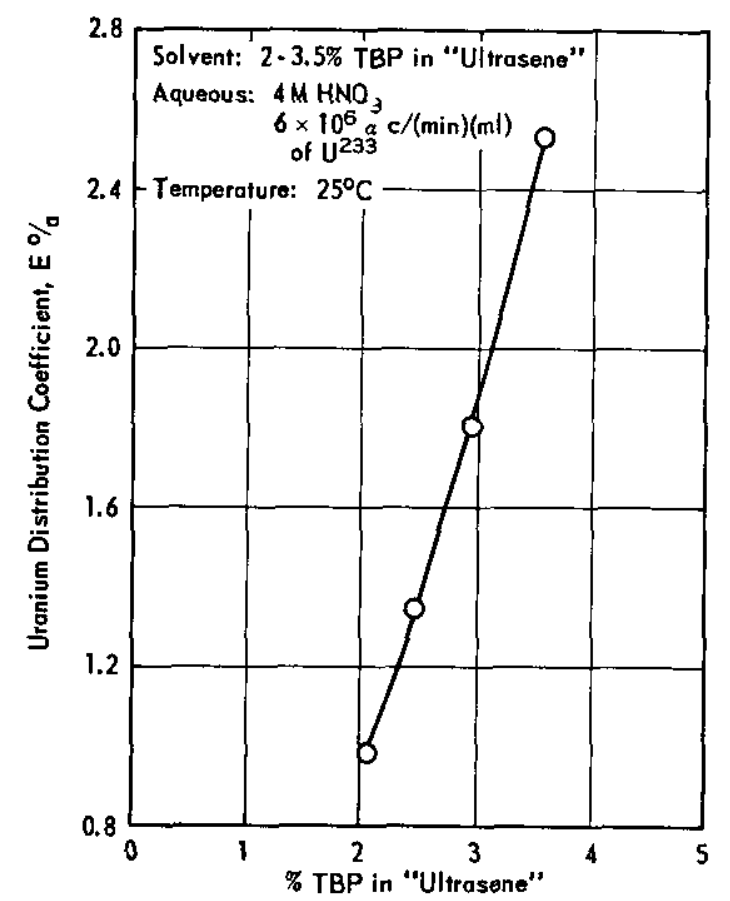

FIG. 14 EFFECT OF TBP ON DISTRIBUTION OF URANIUM, HM PROCESS

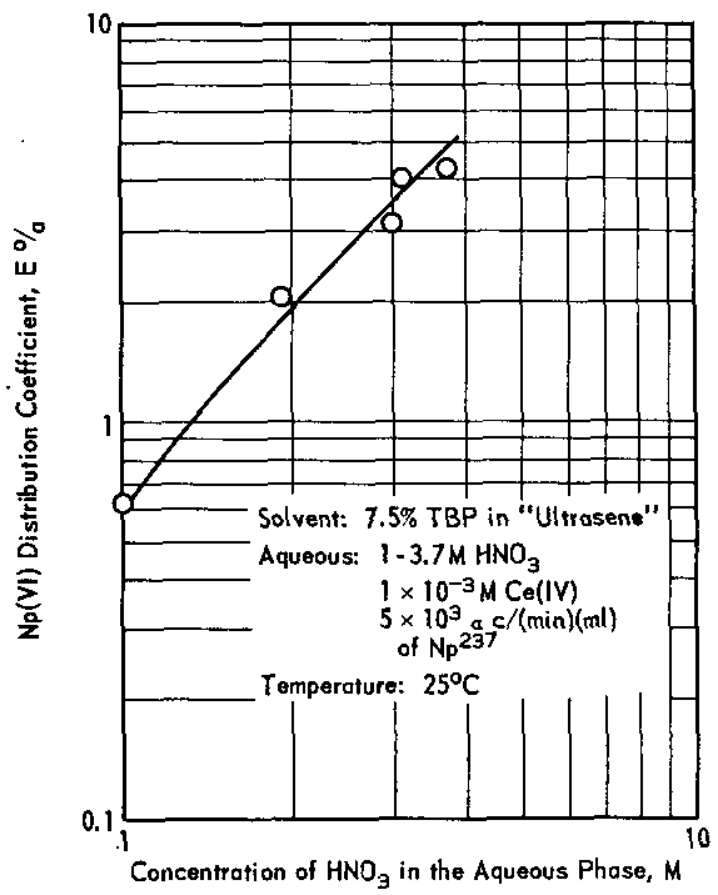

FIG. 16 DISTRIBUTION OF NP(VI), HM PROCESS 
UNCLASSIFIED

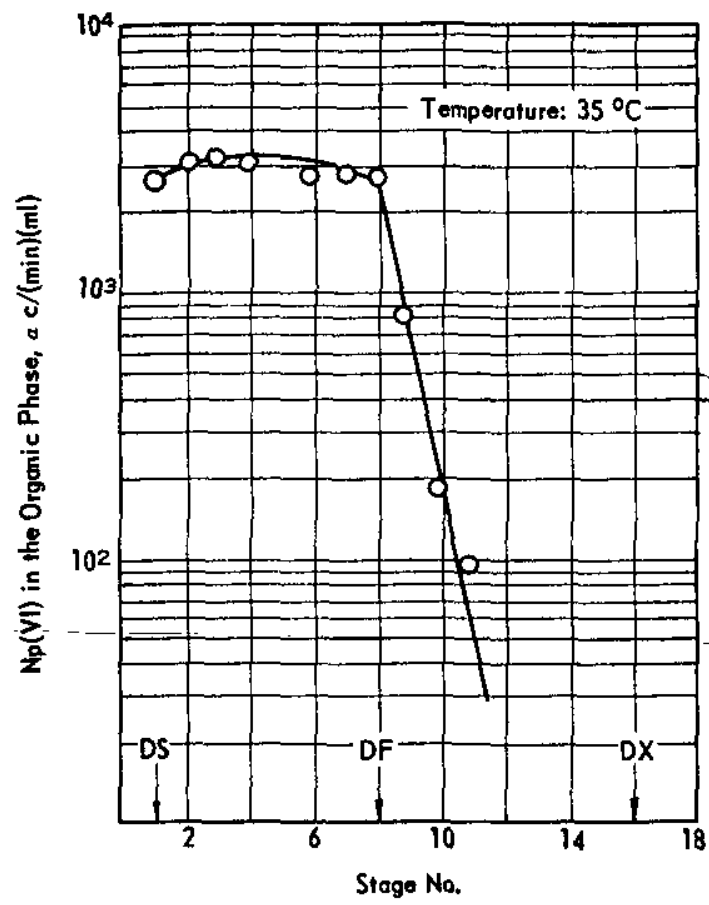

FIG. 17 STAGE PROFILE OF Np(VI) IN ORGANIC PHASE OF ID BANK, OXIDATION WITH CE(IV), HM PROCESS

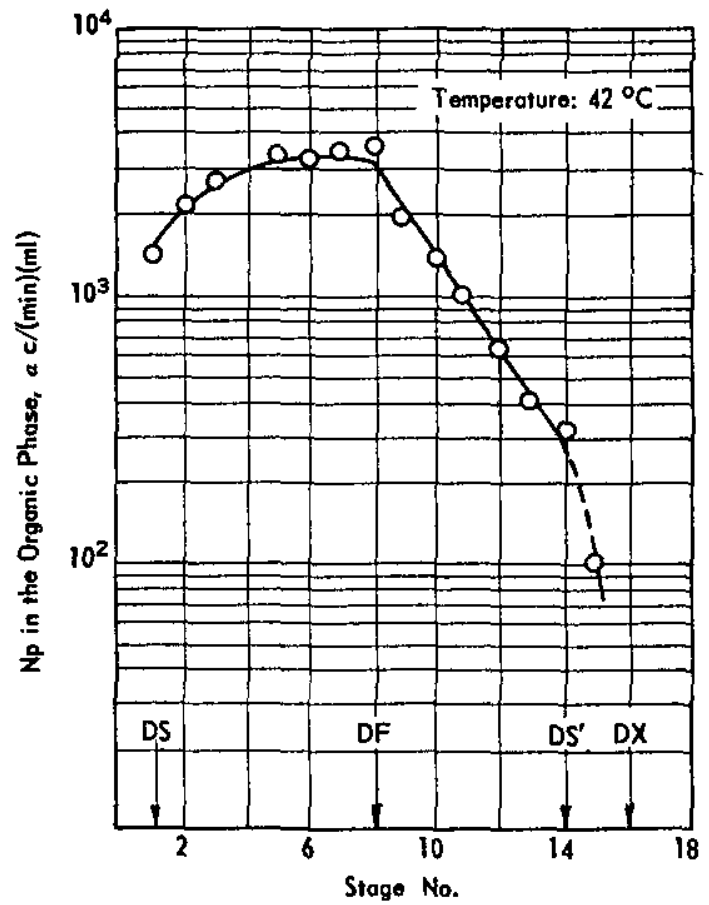

FIG. 19 STAGE PROFILE OF NP IN ORGANIC PHASE OF ID BANK, $0.0005 \mathrm{M} \mathrm{HNO}_{2}$ IN THE ORGANIC PHASE, HM PROCESS

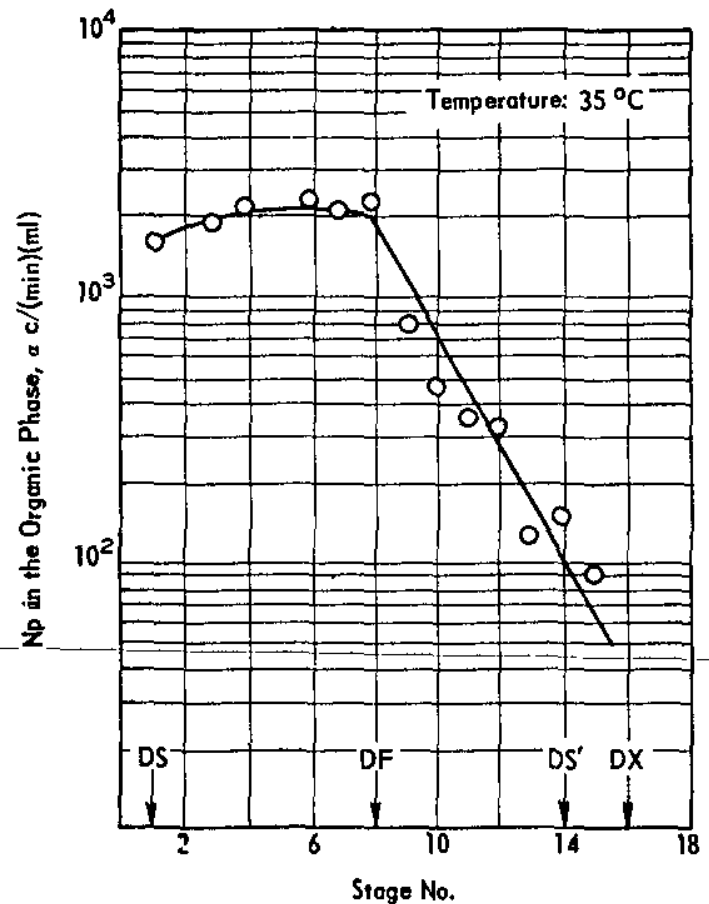

FIG. 18 STAGE PROFILE OF NP IN ORGANIC PHASE OF ID BANK, $0.001 \mathrm{M} \mathrm{HNO}_{2}$ IN THE ORGANIC PHASE, HM PROCESS

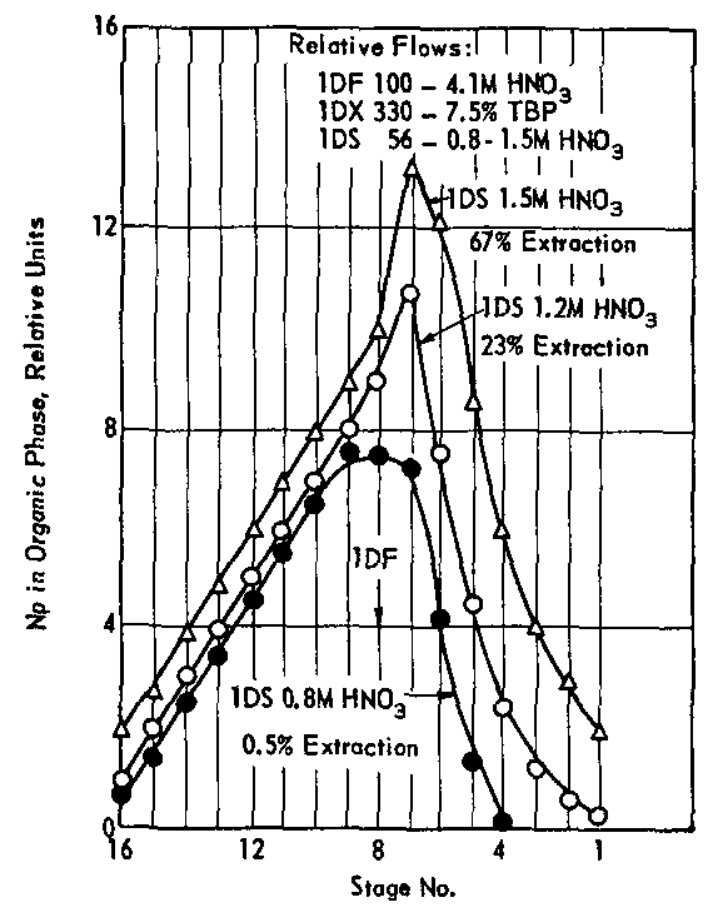

FIG. 20 CALCULATED STAGE PROFILE OF NP(IV) IN ORGANIC PHASE OF ID BANK, HM PROCESS

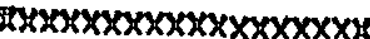
$X \times X \times X \times X \times X \times X \times X \times X \times X X$ $x \times x \times x \times x \times x \times x \times x$

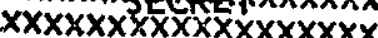

